対照群との間で有意の傾泃が見られた，成分Iの振幅増 加の結果から，釄酸マンガン投与の影響により，聴覚伝 導路に括汿る抑制伝達物質であるセロトニンの減少が推 測された。

今後，エノアミンを测定し，それらが BSR にどのよ う火関与するのかを検討し，生理的手法に上り，金属中 毒をより磪実唖じられるよう，研究を進めていく予定 である。

$$
\text { 座長のまとめ }(251 \sim 253)
$$

太田武夫（岡山大医衛生）

251（東北大・渡辺）は血中マンガン濃度のバックグ ラウンド值および変動要因をさぐるうとするもので, 演 者らの多数处理方法を用いて多数の検体を測定したもの で岕る，性差，地域差，年齢差のあるこそが推定できる が，より明確にするためにさらに試料・結果の蓄積が期
待された。

252 (松下産業衛生科学セ・大原) は作業者の衣服への マンガン付着，洗浄効果を評洒しようとするるのであ る．有害物暴露機会を抑制するために実際的な研究であ る。作業実態汇対応した評価，衣服の材質，上衣以外一 の付着等今後の検討を期待したい。

253 (北大・高橋) はラットに括ける穾験的マンガン中 毒で聴性脳幹反応を観察したものである、マンガンが脳 内モノアミンの変化涼響を与兄る事に上り，中毒特有 の症状を薏起するのか，あるいは組織学的変化が主病変 をなすのかを実験条件を十分吟味して检討する必要があ ろら.

他の金属を含め中权系への作用を生理学的佁険討する 意義の一つのモデルとして興味深いものである.

\title{
【その他金属】
}

\section{4. 鉱山周辺地域住民の毛髮叫各種金属の変動}

町田和彦122，菅原和夫 ${ }^{11}$ ，島岡 章1)

脇阪一郎 ${ }^{22}$ ( ${ }^{(1)}$ 大分医大公衛， ${ }^{2}$ 国立公害研環境保健） 松原純子(東大医疫学)

各種有害金属の過唾摂取から和こる急性特よび慢性中 毒やその逆で方る食生活の変化から最近不足が指摘され ている各種ミネラルの問題, また $\mathrm{Hg}$ と $\mathrm{Se}, \mathrm{Cd}$ そ $\mathrm{Zn}$ 等金属間の相互作用等生体汇与兄る各種元素の影響は最 近注目されてきている，そこで生体内各種元素を健康管 理に用いる一環として，いるいろな面でやりやすい毛髮 を用いて生体内蓄積性を知る試みを行ってきた，今回は その基碟的検討として，鉱山周辺地域とそのコントロー ル地域を中心とした東北地方 3 県 6 地域の住民の毛髧を 材料とし，毛鬅処理の差による各元素の濃度美，扔も火 鉱山との関係からみた各種金属の地域差和よび各元素間 の相関汭て報告した。

洗浄法としては IAEA の方法を用い， $\mathrm{Na}, \mathrm{Mg}, \mathrm{Al}$, $\mathrm{P}, \mathrm{Ca}, \mathrm{Ti}, \mathrm{Mn}, \mathrm{Fe}, \mathrm{Cu}, \mathrm{Zn}, \mathrm{Sr}, \mathrm{K}$ ほプラズマ発光 分光分析 $(\mathrm{ICAP})$ を, $\mathrm{Cd}$ と $\mathrm{Pb}$ はフレームレス原子吸 光法で，Hg はスギャマゲンの水銀分析計它用いた，它 の結果, シャンプーとリンスの影響は未処理群とくらべ 男女同様な傾向で增減したものはみられなかったが，パ 一マ群は $\mathrm{Mg}, \mathrm{Ca}, \mathrm{Sr}$ のアルカリ土金属がすべて未処 理群の 2 倍近い值宗した. 地区別濃度差では現在も $\mathrm{Cd}$ 污染で問題となっている小坂地方で $\mathrm{Cd}$ がとくに高 く，悉た， $\mathrm{Cu}, \mathrm{Pb}$ 鉱山として戦前より大規模な操業を していた尾去沢地方で $\mathrm{Cu}, \mathrm{Zn}, \mathrm{Pb}$ がとくに高いなど
有害金属の地域分布と毛髮中有害金属浀度差沙よく一致 した．次に各元素間の相関をみるために，(1)アルカリ金 属 $(\mathrm{Na}, \mathrm{K})$ ，(2)アルカリ土金属 ( $\mathrm{Mg}, \mathrm{Ca}, \mathrm{Sr})$, (3)必 須金属 ( $\mathrm{A} 1, \mathrm{P}, \mathrm{Ti}, \mathrm{Fe}$ ), (4)必須だが環境污染金属飞る なる金属 $(\mathrm{Mg}, \mathrm{Cu}, \mathrm{Zn})$ ，(5)有害金属 $(\mathrm{Cd}, \mathrm{Hg}, \mathrm{Pb})$ の順に並べ比較したところ，(1)（3)はとの各群中で互い に相関が高く，また(3)と(4)の各元素間も高い相関安示し た. しかし(5)の金属相互の相関は淁とんど認められなか った.

255. 金属イオンの NK 細胞に対する影響 (III) 加藤芳郎，毛利靖彦，鳥海久雄 小森義隆，皿井 進 (大同病院)

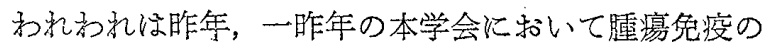
重要な役割をるつNK七ト活性汇対して，種々の金属イ オンが影響を与えることを報告してきた。，今回われわれ はこれら金属の NK 活性に対する作用機序を標的細胞と NK 細胞との結合能といら観点より検討を行った。

$<$ 方法> 健常者 4 名の末梢静脈血中単核球をFicollConray 比重遠沈法にて型ど括り分離し以下の実駼に用

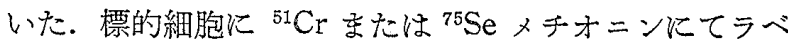
ルした K 562 細胞を用いた。、マイクロプレートを用い 単核球との此を $40: 1$ 亿て $37^{\circ} \mathrm{C} 4$ 時間浮置し上清に放 出された放射能を測定し \% NK 活性を算定し，13 䅉類 の金属について NK 活性の変動々標的細胞に対する影響 を検討した，標的細胞結合リンパ球の測定は以下のと拉 り行った．単球叔よび非特異的結合細胞除去の目的で分 離単核球浮遊液をナイロンウールカラムを通過させ，こ 